\title{
A new species of Pacifigorgia (Coelenterata: Octocorallia: Gorgo- niidae) from Panamá
}

\author{
ODALISCA BREEDY ${ }^{1} \&$ HÉCTOR M. GUZMÁN ${ }^{2}$ \\ ${ }^{1}$ Museo de Zoología, Escuela de Biología, Universidad de Costa Rica, P.O. Box 1962-2100, San José, Costa \\ Rica,odalisca@racsa.co.cr \\ ${ }^{2}$ Smithsonian Tropical Research Institute P.O. Box 2072, Balboa,Panamá,guzmanh@naos.si.edu
}

\begin{abstract}
Pacifigorgia rubinoffi, a new shallow water species of the family Gorgoniidae from the Pacific Panamá, is described and illustrated. Known from several localities around the Gulf of Chiriquí, it is patchy in distribution, ranging from 1-5 $\mathrm{m}$ in depth. The colony is characterized by multiple fans, closed meshwork, lack of distinct midribs, a deep orange color of both colony and sclerites, low occurrence of spindles with acute and bent ends, large asymmetric rods, and the occurrence of barrels. The new species is illustrated in detail with scanning electron micrographs, photomicrographs and color photographs.
\end{abstract}

Key words: Cnidaria, Coelenterate, eastern Pacific, gorgonians, Gorgoniidae, octocorals, Pacifigorgia, Panamá, sea fans, soft corals, Taxonomy

\section{Introduction}

Gorgonians are commonly found along the Pacific coast of Panamá, ranging widely in distribution and depth. The first reports that exist of this fauna came from Valenciennes (1855), Verrill (1866, 1868), Hickson (1928), and Stiasny (1943). These authors recorded around 48 species comprising the genera Pacifigorgia, Leptogorgia, Eugorgia, Psammogorgia, Muricea, and Heterogorgia. With the exception of Pacifigorgia, the other genera occurring in the eastern Pacific are in need of revision. The genus Pacifigorgia has been subject to revision in the course of current research (Breedy \& Guzmán 2002). In addition to the 9 species of Pacifigorgia reported for Panamá, we have observed five more species of the genus. Recent expeditions carried out in the Gulf of Chiriquí revealed that the genus Pacifigorgia is highly represented in terms of abundance and diversity. In this paper, we describe a new shallow water species of Pacifigorgia with detailed illustrations of multiple specimens collected at several localities. 
Specimens were collected by diving from $1.5-5 \mathrm{~m}$ in depth, at different localities in the Gulf of Chiriquí, southwest Pacific of Panama (Fig. 1). Colonies were air dried or fixed in $70 \%$ ethanol. Sclerites were prepared for light and scanning electron microscopy (SEM) following the standard techniques for ultra structural analysis (Bayer 1961, Breedy \& Guzmán 2002).
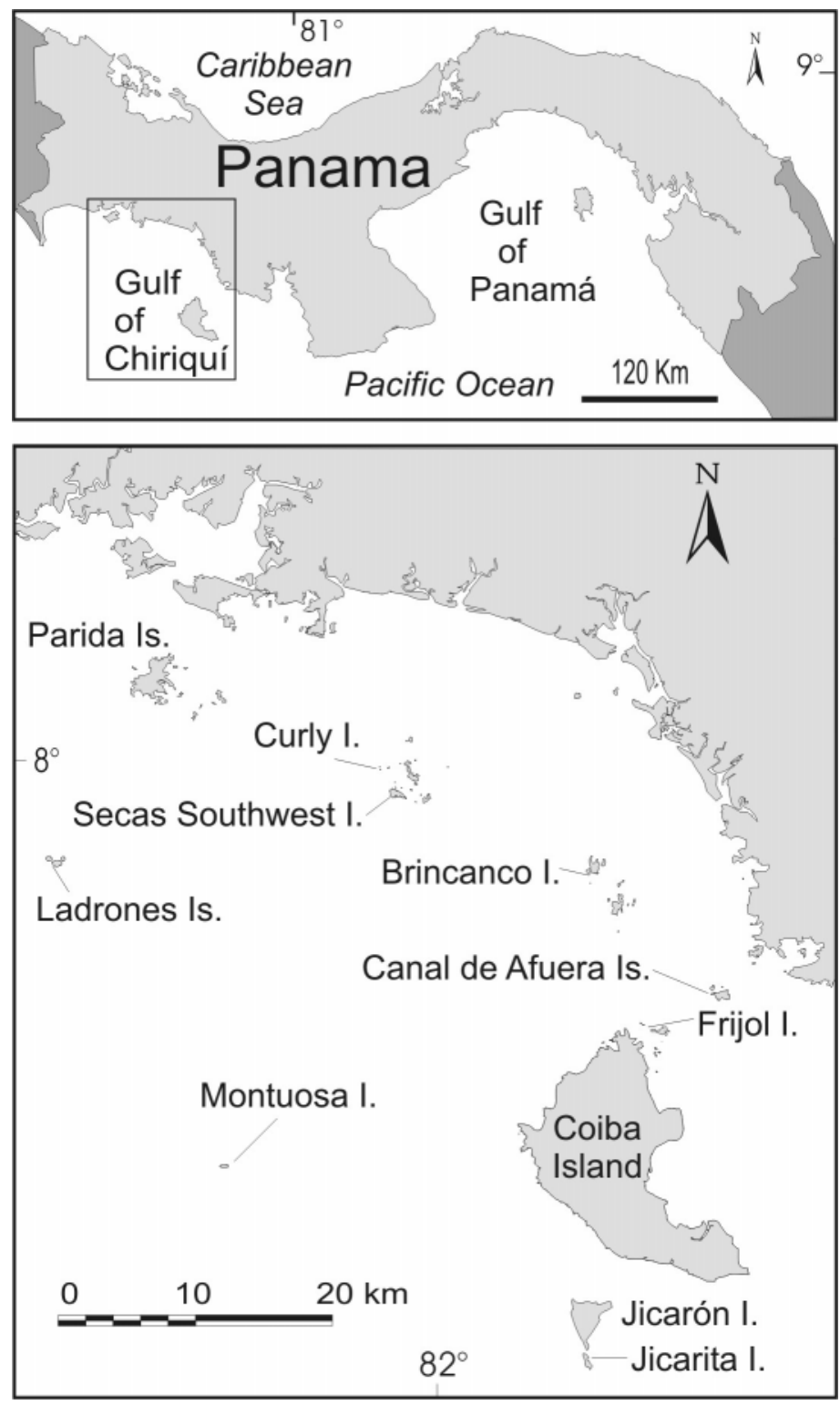

FIGURE 1. Map of Panamá with a detail of the Gulf of Chiriquí, showing the sites where Pacifigorgia rubinoffi $\mathrm{n}$. sp. was found. 
The holotype was deposited in the Museo de Zoología, Escuela de Biología, Univer-

sidad de Costa Rica (UCR), and paratypes were deposited in the UCR, and the Museum of Comparative Zoology, Harvard University, Cambridge, USA (MCZ).

\section{GORGONIIDAE Lamouroux, 1812}

\section{Pacifigorgia Bayer, 1951}

Rhipidigorgia (partial) Valenciennes, 1855: 13. Milne Edwards \& Haime, 1857: 173. Horn, 1860: 233.

Rhipidogorgia (partial). Verrill, 1864: 32. Duchassaing \& Michelotti, 1864: 20. Verrill, 1869: 424.

Litigorgia (partial) + Eugorgia (partial) Verrill, 1868: 414.

Leptogorgia (partial) Verrill, 1869: 420. Verrill, 1870: 548.

Gorgonia. Bielschowsky, 1918: 32. Kükenthal, 1924: 338. Bielschowsky, 1929: 141. Stiasny, 1941: 268. Stiasny, 1943:74.

Pacifigorgia Bayer, 1951: 94. Breedy, 2001. Breedy \& Guzmán, 2002:

Type species. Gorgonia stenobrochis Valenciennes, 1846, by original designation (Bayer 1951: 94).

Description. Colonies flabellate, branched in one or several parallel planes. Branches regularly anastomosed to form a network of meshes of various dimensions. Calyces absent or raised only slightly above surface of the coenenchyme. Coenenchymal sclerites basically of three kinds: long spindles with acute ends and several whorls of warts; long (up to $0.2 \mathrm{~mm}$ ) or short (around $0.06 \mathrm{~mm}$ ) blunt spindles with several whorls of warts; and capstans ornamented with different levels of complexity. Anthocodial sclerites flattened rods with smooth, scalloped, indented or lobed margins.

Remarks. Of the 27 species of Pacifigorgia known for the eastern Pacific, 13 have been observed in the Pacific of Panama.

Distribution. Eastern Pacific, from southern California to Chile and the Galápagos Islands; Atlantic coast, only one species (Pacifigorgia elegans) from Trinidad to Brazil (Bayer 1951), and observed in Venezuela (pers. obs.).

\section{Pacifigorgia rubinoffi new species}

Figures 2-4

Material examined. Southwest Brincanco Island, Gulf of Chiriquí, Panamá, 1-4 m, 26 April 2002, dry, UCR 1024 (STRI 339), holotype. Northwest Canal de Afuera Islands, Gulf of Chiriquí, Panamá, 1-4 m, 10 December 2001, coll. H.M. Guzmán, MCZ 50655 (STRI 16), preserved in ethanol, UCR 1027 (STRI 16A), dry, paratype. Frijol South Islet, Gulf of Chiriquí, Panamá, 1-4 m, 25 April 2002, coll. H.M. Guzmán, UCR 1024 (STRI 324), 1025 (STRI 325), dry paratypes. Frijol South Islet, Gulf of Chiriquí, Panamá, 1-4 m, 
24 August 2002, coll. H.M. Guzmán \& O. Breedy, UCR 1028 (STRI 391), dry, paratype. Curly Islet, Gulf of Chiriquí, Panamá, 1-4 m, 25 August 2002, coll. H.M. Guzmán \& O. Breedy, UCR 1029 (2) (STRI 398), preserved in ethanol, paratype. Southwest Brincanco Island, Gulf of Chiriquí, Panamá, 1-5 m, 24 August 2002, coll. H.M. Guzmán \& O. Breedy, MCZ 50656 (STRI 395), dry paratype.

Other material. Curly Islet, Contreras Archipelago, Gulf of Chiriquí, Panamá, 1-4 m, 25 August, 2002, coll. H.M. Guzmán \& O. Breedy, ten colonies preserved in ethanol, to be used in other studies.

Holotype. Colony measures $21 \mathrm{~cm}$ in height, and $26 \mathrm{~cm}$, consists of a main fan and 3 small secondary fans. Colony arises from an oval, strong holdfast ( $15 \mathrm{~mm}$ in diameter). It has three thick branches (about $5 \mathrm{~mm}$ in diameter at the base) that reach up to the middle of the colony; the secondary fans sprout from them and radiate perpendicular to the main fan. No distinct midribs are present. Meshwork is regular, and closed, of mostly round meshes (up to 9 by $5 \mathrm{~mm}$ in diameter). Color of the colony is a bright deep orange (Fig. 2A). Calyces are round, slightly raised with slit-like apertures. Calyces are arranged not very close, distributed mostly in two rows on all sides of the branches, but in three or more rows on the thick branches (Figs. 2C, D, 3). Polyps are white, fully retractile into the coenenchyme (Fig. 2D). Anthocodiae are weakly armed with collaret-like masses of slender orange and yellow rods at the base of the tentacles. The most common coenenchymal sclerites are capstans (Fig 4B) measuring $0.04-0.08 \mathrm{~mm}$ by $0.02-0.06 \mathrm{~mm}$. They have a distinct waist and clusters of closely group tubercles at either end. Some show a tendency to have two whorls of tubercles (Fig 4Ba) and are intermediate to the coenenchymal spindles. The spindles (Fig 4A) vary from $0.09-0.1 \mathrm{~mm}$ in length and $0.05-0.06 \mathrm{~mm}$ in width. They generally have from two to four whorls of tubercles and the sclerite's tips can be blunt or acute. The longer spindles tend to be narrow, with acute tips that can be slightly curved. On some spindles the tubercles are irregularly arranged, such as Fig 4Aa,b. Amongst the coenenchymal sclerites are some crosses, up to $0.1 \mathrm{~mm}$ in diameter (Fig. 4C), and some conspicuous barrel- or oval-shaped sclerites up to $0.07 \mathrm{~mm}$ long (Fig. 4D). A number of immature sclerite forms (Fig 4F) are also present. Sclerites are all usually deep orange or dark yellow. Anthocodial sclerites are light orange, somewhat flattened rods up to $0.07 \mathrm{~mm}$ by $0.03 \mathrm{~mm}$ with mostly smooth or lobed margins (Fig. 4E). Spindly capstans, in small numbers, were also in the preparations of sclerites, as in most of the species of this genus.

FIGURE 2. Pacifigorgia rubinoffi n. sp. A) holotype colony, dry specimen; B) living colonies photographed at $2 \mathrm{~m}$ deep in Frijol Islet; C) detail of the branches; D) branches showing the polyps; E) photomicrograph of sclerites showing their characteristic orange color. 

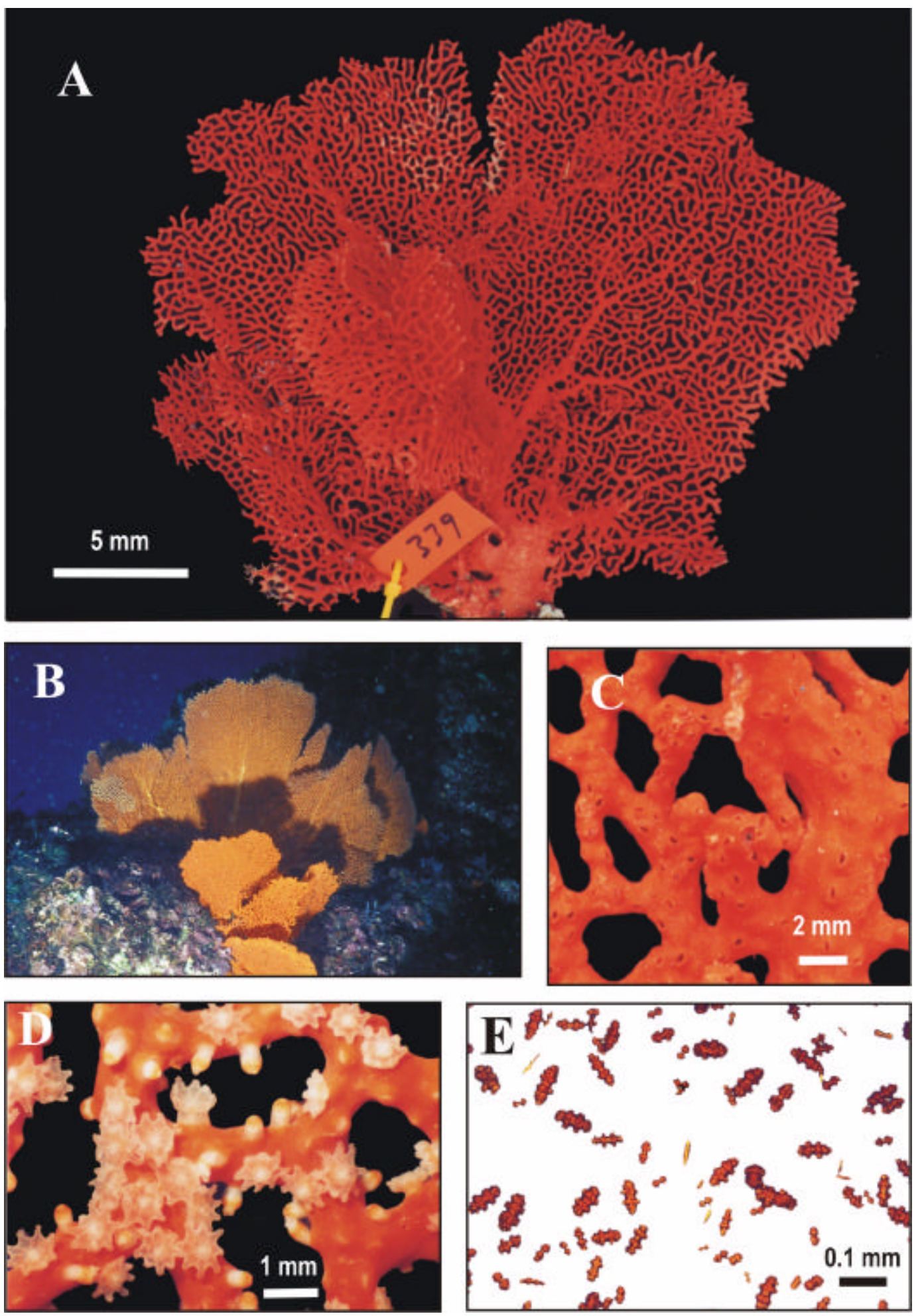
Description. Colonies are wider than high, up to $25 \mathrm{~cm}$ in height, and $35 \mathrm{~cm}$ in width, composed of several reticulate fans. Fans arise from strong, laminar holdfasts covered with coenenchyme bearing scarce, distant polyps, and spread over solid substrate. New branches and secondary fans originate directly from the holdfast, growing perpendicularly and forming complex multiplanar arrangements that also can be observed in small colonies. Several thick branches, up to $5 \mathrm{~mm}$ in diameter, can be traced from the base of the colonies and extend for some distance, but no distinct midribs totally cross the fans. Thinner branches, 1-2 mm in diameter, form a regular network of close meshes (around 11 meshes $/ \mathrm{cm}^{2}$ ), mostly round or squarish, without angular corners, and up to 9 by $5 \mathrm{~mm}$ in size. End-branchlets are up to $7 \mathrm{~mm}$ in length, and there are few, short free-twigs that project into the lager meshes. Axes of the thick branches look dark purple, due to the color of the axial sheath sclerites (P. Alderslade, pers. comm.) and they are of a straw color in the thinner branches. Calyces and polyps are as described for the holotype. Color of the colonies, varies from a colorful deep orange (Fig. 2 A, B, C), to a dark yellow (paratype UCR 1026). In some preserved specimens (dry or ethanol), the sclerites around the apertures of the calyces are lighter than the others and form pale yellow rings (e.g. paratypes UCR 1028, MCZ 50655 (STRI 16)). Sclerites are as described for the holotype, with some variation in color, from deep orange to dark yellow. Some variation exists also in the abundance of types of sclerites, for example in the paratype MCZ 50655 (STRI 16), spindles with acute ends are more abundant in the microscopic preparations of sclerites, than they are in the holotype.

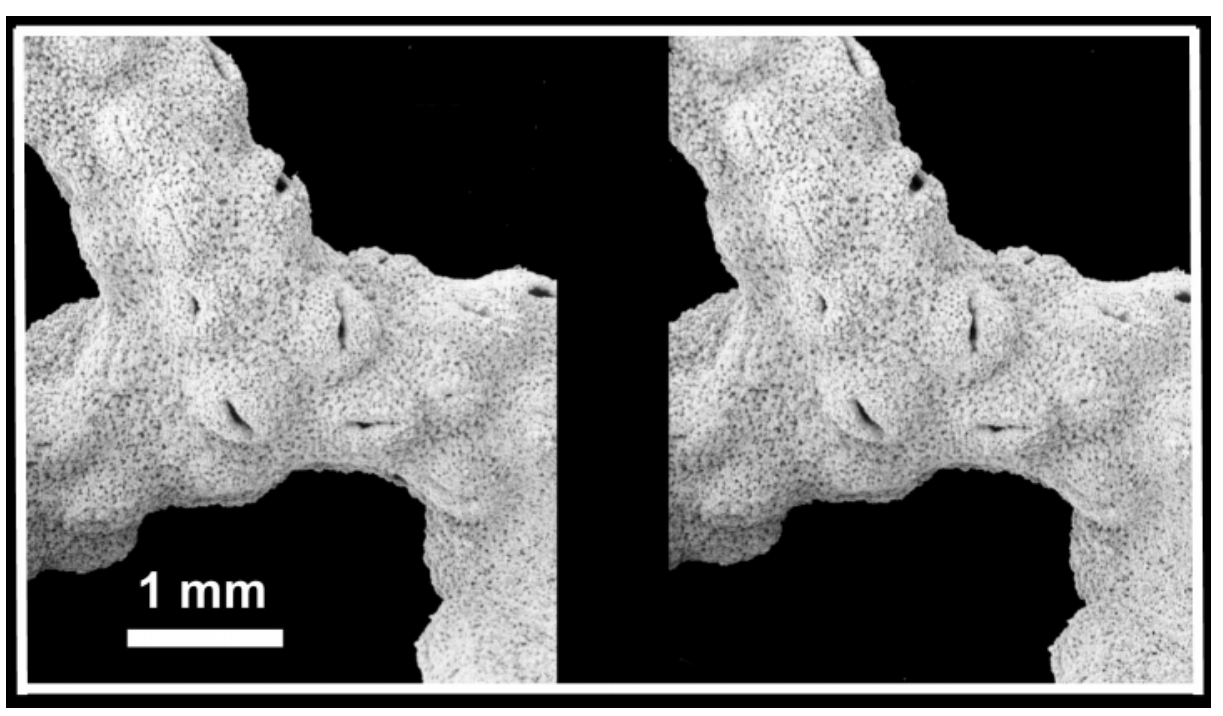

FIGURE 3. Pacifigorgia rubinoffi n. sp., SEM-micrograph stereo pair of a branch from the holotype.oni 
Etymology. We dedicate this species to Dr. Ira Rubinoff, who has been the Director of the Smithsonian Tropical Research Institute (STRI) since 1973; his vision and combination of political skill and scientific knowledge has made STRI one of the world's best center for basic research in the tropics.

Remarks. The new species differs from other taxa in Pacifigorgia by having the following combination of characters. First, the colony is composed of multiple fans, a closed meshwork, a lack of distinct midribs, and a conspicuous orange color of both colony and sclerites. Second, it has a low occurrence of spindles with acute ends; in some colonies, however, an increase of this type is evident in the sclerite-preparations; the occurrence of spindles with bent ends, instead of the more common type with straight ends. The presence of large, conspicuous, asymmetric rods; and the occurrence of barrels are also distinctive features. Finally, the anthocodial rods have mostly smooth borders and reach no more than $0.07 \mathrm{~mm}$ in length.

Habitat. Populations of this species were found in shallow water from 1.5 to $5 \mathrm{~m}$ at eight sites only in the Gulf of Chiriquí; they grow on rocky substrates in zones of strong swell and currents. Populations are patchily distributed, but can constitute the dominant species in a small $(<550 \mathrm{~m} 2)$ area. Population abundance (number of colonies) was recorded at each site (see Fig. 1); 6 individuals in Canal de Afuera Islands, 38 in Frijol South Islet (near Coiba Island), 2 in Curly and Secas West Islets (Secas Archipelago), 3 in Ladrones Islands, 5 in Montuosa Island, 3 in Jicarita Island, and the largest population of ca. 323 colonies in Brincanco Island (Contreras Archipelago) composed of a large number of recruits. The species often co-occur with individuals of another new species of Pacifigorgia (pers. obs.), Leptogorgia alba Duchassaing \& Michelotti, and another small undetermined species of Leptogorgia.

Distribution. Gulf of Chiriquí, Panamá.

\section{Acknowledgements}

We are grateful to Leen van Ofwegen (National Museum of Natural History Naturalis, Leiden), Stephen Cairns (National Museum of Natural History), Phil Alderslade (Museum and Art Gallery of the Northern Territory), and Manfred Grasshoff (Forschungsinstitut und Naturmuseum Senckenberg, Frankfurt) for their critical review and comments. This project was partially sponsored by the Fundación AVINA (Costa Rica) and the Smithsonian Tropical Research Institute (Panamá). Specimens were collected during several cruises to study the Gulf of Chiriquí on board the R/V Urracá, and we offer our appreciation of the assistance by the Captain and crew. We thank Carlos Guevara for his support in the field. We thank Enrique Freer for providing the facilities of the Centro de Investigación en estructuras microscópicas, Universidad de Costa Rica, Van Wallach (MCZ) for the efficient following of our paratypes, and Percy Denyer (Universidad de Costa Rica) for the preparation of the figures. 
ZOOTAXA

128

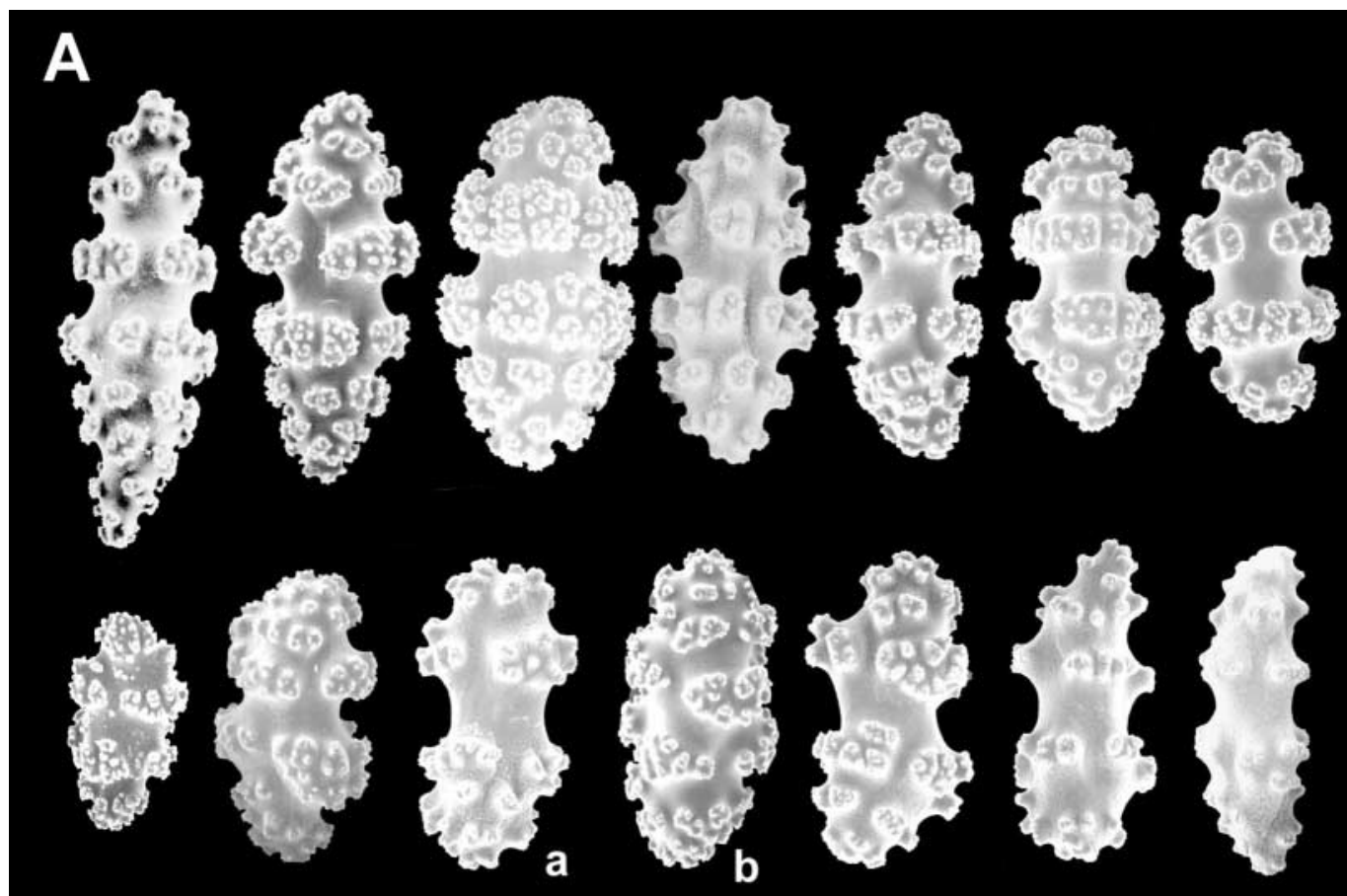

\section{B}

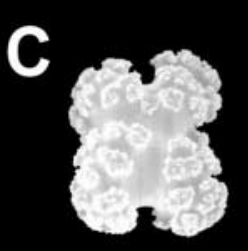

C

\& ?

?

8

E

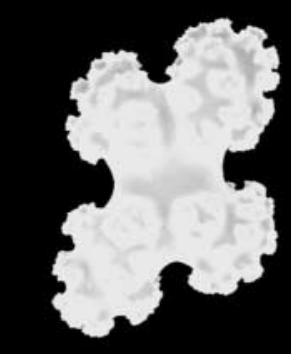

D

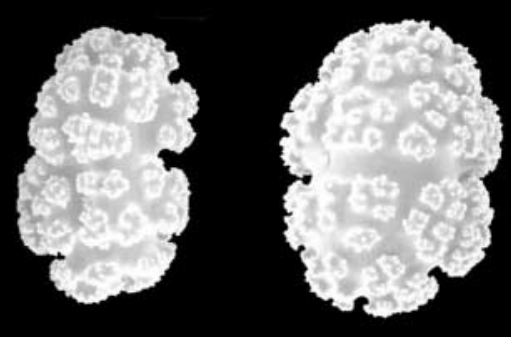

F

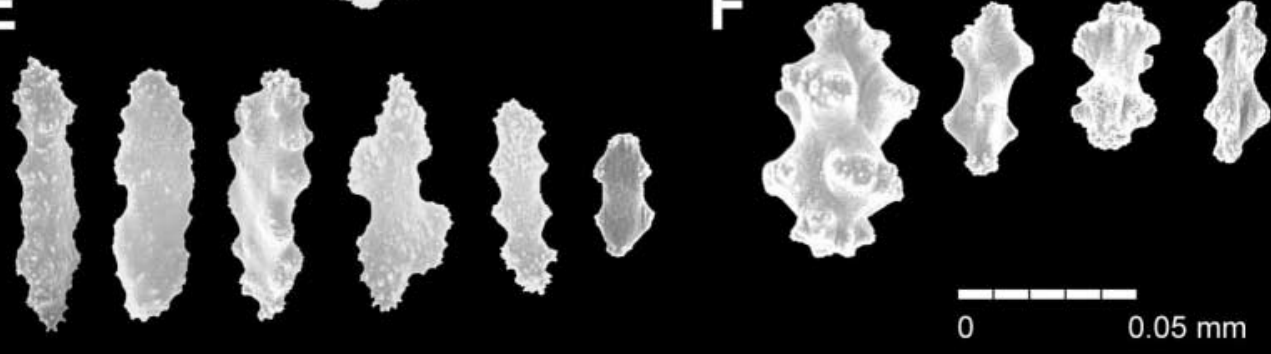


FIGURE 4. Pacifigorgia rubinoffi n. sp., SEM-micrographs of the sclerites, holotype. A) spindles with acute ends; A a,b) spindles with irregularly arranged tubercules; B) capstans; B a) capstans with intermediate forms to spindles; C) crosses; D) barrel- or oval-shaped sclerites; E) anthocodial flat rods; F) immature sclerite forms.

\section{References}

Bayer, F.M. (1951) A revision of the nomenclature of the Gorgoniidae (Coelenterata: Octocorallia) with an illustrated key to the genera. Journal of the Washington Academy of Sciences, 41, 91102.

Bayer, F.M. (1961) The shallow water Octocorallia of the West Indian Region. A manual for marine biologists, Martinus Nijhoff, The Hague, 400 pp.

Bielschowsky, E. (1918) Eine Revision der Familie Gorgoniidae. Inaugural-Dissertation zur Erlangung der Doktorwürde der Hohen Philisophischen Facultät der Schelesischen Friedrich-Wilhelms-Universität zu Breslau, Buchdruckerei H. Fleischmann, Breslau, 66 pp.

Bielschowsky, E. (1929) Die Gorgonarien Westindien. 6. Die Familie Gorgoniidae, zugleich eine Revision. Zoologische Jahrbücher, Supplement 16, 63-234.

Breedy, O.(2001) A new species of Pacifigorgia from the eastern Pacific (Coelenterata: Octocorallia: Gorgoniidae). Bulletin of the Biological Society of Washington, 10, 181-187.

Breedy, O. \& Guzmán, H.M. (2002) A Revision of the genus Pacifigorgia (Coelenterata: Octocorallia: Gorgoniidae). Proceedings of the Biological Society of Washington, 115, 787, 844 (in press).

Duchassaing, P. \& Michelotti, J. (1864) Supplément au mémoire sur les coralliaires des Antilles. Extrait des mémoires de l'Académie des Sciences de Turin, 23, 1-112.

Hickson, S. J. (1928) The Gorgonacea of Panama Bay together with a description of one species from the Galapagos Islands and one of Trinidad. Videnskavelige Meddelelser fra den naturhistoriske Forening $i$ Kovenhavn for Aarene, 85, 325-422.

Horn, G. H.(1860) Descriptions of three new species of Gorgonidae, in the collection of the Academy. Proceedings of the Academy of Natural Sciences of Philadelphia, 12, 233.

Kükenthal, W. (1924) Gorgonaria. Berlin und Leipzig, Walter de Gruyter and Company, 478pp.

Lamouroux, J. V. F. (1812) Extrait d'un mémoire sur la classification des Polypiers coralligènes non entièrement pierreux. Nouveau Bulletin des Sciences, par la Société Philomatique, Paris, 3, 181-188.

Milne Edwards, H. \& Haime J. (1857) Histoire naturelle des coralliaires ou polypes proprement dits, Vol. 1. Pp. xxxiv + 1-326, 8 plates, numbered A1-6, B1-2. Paris, à la Libraire Encyclopédique de Roret.

Stiasny, G. (1941) Studien uber Alcyonaria und Gorgonaria I-V. (Parerga und Paralipomena). Zoologische Anzeiger, 133, 268-271.

Stiasny, G. (1943) Gorgonaria von Panama. Aus der Sammlung Dr. Th. Mortensen, Zoologisk Museum, Kopenhagen. Videnskavelige Meddelelser fra den naturhistoriske Forening i Kovenhavn for Aarene, 107, 59-103.

Valenciennes, A. (1846) Zoophytes. In: Abel Dupetit-Thouars, Voyage autour du monde sur la frégate la Vénus, pendant les années 1836-1839. Atlas de Zoologie, pls. 1-15.

Valenciennes, A. (1855) Extrait d'une monographie de la famille des Gorgonidées de la classe des polypes. Countes Resus Académie des Sciences de Paris, 41, 7-15. 
Verrill, A. E. (1864) List of the polyps and corals sent by the Museum of Comparative Zoölogy to other institutions in exchange, with annotations. Bulletin of the Museum of Comparative Zoölogy at Harvard College, 1, 29-60.

Verrill, A. E. (1866). On the polyps and corals from Panama with descriptions of new species. Proceedings of the Boston Society of Natural History, 10, 323-357.

Verrill, A. E. (1868) Notes on Radiata in the Museum of Yale College, Number 6: Review of the corals and polyps of the West Coast of America. Transactions of the Connecticut Academy of Arts and Sciences, (Second Edition), 1, 377-422.

Verrill, A. E. (1869). Critical remarks on the halcyonoid polyps with description of new species in the Museum of Yale College. The American Journal of Science and Arts, 48, 419-429.

Verrill, A. E. (1870) Notes on Radiata in the Museum of Yale College, Number 6: Review of the corals and polyps of the West Coast of America. Transactions of the Connecticut Academy of Arts and Sciences, (Second Edition), 1, 503-558. 